\title{
Pediatri Hemşirelerinin Duygu Gereksinimleri ile Maneviyat ve Manevi Bakım Hakkındaki Görüşlerinin İncelenmesi $\infty$
}

\author{
Hilal KURT SEZER ${ }^{1}$, Emine GEÇKIL ${ }^{2}$
}

\section{Öz}

Amaç: Çalışmada pediatri hemşirelerinin duygu gereksinimleri ile maneviyat ve manevi bakım hakkındaki görüşlerinin incelenmesi amaçlanmıştır.

Gereç ve Yöntem: Araştırmanın örneklemi Konya il merkezinde çalışan 280 pediatri hemşiresinden oluşmuştur. Veriler Sosyodemografik Bilgi Formu, Duygu Gereksinimi Ölçeği, Maneviyat ve Manevi Bakım Dereceleme Ölçeği ile toplanmıştır. Veriler ortalama, standart sapma, yüzdelik, çoklu regresyon, pearson korelasyon ile analiz edilmiştir.

Bulgular: Hemşirelerin \%80'i kadın, \%58,2'si evli ve \%61,7'si lisans mezunudur. Maneviyat ve Manevi Bakım Dereceleme Ölçeği madde puan ortalaması 3,69 $\pm 0,67$ ve Duygu Gereksinimi Ölçeği toplam puan ortalaması $16,16 \pm 19,15^{\prime}$ dır. Duygu Gereksinimi Ölçeği toplam puan ortalaması incelendiğinde duygusal olaylara olumlu yaklaştığını ifade eden $(p<0,001)$, çocuk ve ailelerin manevi bakım gereksinimleri olduğunu düşünen $(p<0,05)$, deneyimi 5 yıldan fazla olan $(p<0,05)$, kadın olan $(p<0,05)$ ve lisansüstü eğitim yapmış olan $(p<0,05)$ hemşirelerin puanları diğerlerinden anlamlı şekilde yüksek bulunmuştur. Hemşirelerin iki ölçek puanları arasında pozitif yönde orta kuvvette anlamlı bir ilişki olduğu belirlenmiştir $(p<0,05)$.

Sonuç: Özellikle bekar ve erkek, çocuğu olmayan, mesleğe yeni başlayan hemşireler başta olmak üzere tüm pediatri hemşirelerine çocuk ve ailelerinin manevi ve duygusal gereksinimlerini karşılayacak bilgi ve beceri kazandırılması önerilebilir.

Anahtar kelimeler: Duygular, hemşireler, pediatri, maneviyat

\begin{abstract}
Investigation of Pediatric Nurses' Emotional Needs and Their Views on Spirituality and Spiritual Care

Aim: The aim of the study was to investigate pediatric nurses' emotional needs and their views on spirituality and spiritual care. Material and Methods: The study sample consisted of 280 pediatric nurses working in Konya Province. Data were collected by Sociodemographic Information Form, Need For Affect Scale, and Spirituality and Spiritual Care Rating Scale. Data were analyzed with mean, standard deviation, percentile, multiple regression, and Pearson correlation.

Results: Of the nurses, $80 \%$ was female, $58.2 \%$ was married, $61.7 \%$ had Bachelor's degree. Spirituality and Spiritual Care Rating Scale score average was $3.69 \pm 0.67$ and Need For Affect Scale score average was 16.16 \pm 19.15 . Considering Need For Affect Scale score averages, scores of nurses who have a positive approach towards emotional events $(p<0.05)$, who consider children and families need spiritual care $(p<0.05)$, who have $>5$ years of working experience $(p<0.05)$, who are female $(p<0.05)$ and who had a postgraduate degree $(p<0.05)$ were significantly higher. There was a positive and moderately significant relationship between the nurses' scale scores. $(p<0.05)$.

Conclusion: It can be recommended that all pediatric nurses, especially single and male, childless and who are new to the profession, should be provided with the knowledge and skills to meet the spiritual and emotional needs of the children and their families.

Keywords: Emotions, nurses, pediatrics, spirituality
\end{abstract}

${ }^{1}$ Öğr. Gör. KTO Karatay Üniversitesi Sağlık Hizmetleri Meslek Yüksek Okulu İlk ve Acil Yardım Programı, Karatay, Konya, Türkiye, E-mail: hilalkurt26@hotmail.com, Tel: 4441251-7601, ORCID: 0000-0001-8365-0655

2 Prof. Dr. Necmettin Erbakan Üniversitesi, Hemşirelik Fakültesi, Çocuk Sağlığı ve Hastalıkları Hemşireliği Anabilim Dalı, Konya, Türkiye, E-mail: eminegeckil@gmail.com, Tel: 033232040 49, ORCID: 0000-0003-3947-285X

Geliş Tarihi: 11 Kasım 2019, Kabul Tarihi: 11 Mayıs 2020

* Bu çalışma 29 Kasım-2 Aralık 2016 'da 6. Ulusal 1.Uluslararası Pediatri Hemşireliği Kongresinde sözel bildiri olarak sunulmuştur.

Atıf/Citation:Kurt Sezer H, Geçkil E. Pediatri Hemşirelerinin Duygu Gereksinimleri ile Maneviyat ve Manevi Bakım Hakkındaki Görüşlerinin İncelenmesi. Hacettepe Üniversitesi Hemşirelik Fakültesi Dergisi 2020; 7(2): 167-174. DOI: 10.31125/hunhemsire.763183 


\section{GíRiş}

Insan biyolojik, psikolojik, sosyal, kültürel ve tinsel boyutları olan eşsiz bir varlıktır. Bu nedenle hemşireler, sağlık sorunu olan bireyin hemşirelik bakımını planlarken, bireyi bütün boyutları ile ele alırlar ${ }^{1,2}$. Hemşireliğin tarihsel sürecine bakıldığında, bireyin fiziksel, psikolojik ve sosyal boyutlarının daha kapsamlı olarak ele alınabildiği görülmektedir2,3. Buna karşın bireyin spiritüel boyutuna yönelik çalışmaların ise daha yeni olduğu söylenebilir. Günümüzde spritüel bakım (manevi bakım) hemşireler tarafından daha fazla anlaşılmakta ve kabul görmektedir ${ }^{4,5}$.

Hemşirelikte manevi bakımın hedefi, hemşirenin bakım verdiği bireyin ve kendisinin duygularının farkında olmasına, hastanın yaşamının amacını anlamasına, iç huzura kavuşmasına, hastalıkla mücadelede motivasyon ve moral gücü bulmasına ve manevi olarak kendisini huzurlu hissetmesine yardım etmektir6,7.

Manevi bakım genellikle yaşamı tehdit edici hastalığı olan bireylerde acı çekme, yalnızlık hissi ve izolasyonu azaltmaya yönelik bir bakım olarak düşünülmektedir. Ancak manevi bakımın bütün hastalar için gerekli olduğu göz ardı edilmemelidir8,9. Manevi bakım, hemşirelerin bütün hastaları spirituel yönden değerlendirmesini, dinlemesini, zaman ayırmasını, empati yapmasını ve terapötik iletişim tekniklerini kullanmasını gerektiren duygu yüklü bir bakım alanıdır7,10. Ayrıca manevi bakım aktif dinleme, suskunluğu paylaşabilme, dokunmayı etkili kullanabilme, ağrılı ve terminal dönemdeki bireye yarım edebilme gibi duygusal dayanıklılık isteyen becerileri gerektirir ${ }^{11,12}$. Hemşireler, duygu gereksinimlerine bağlı olarak manevi bakım gibi duygu yoğunluğu olan aktivitelere katılma veya kaçınma yönünde davranışlar sergileyebilir. Hemşirelikte manevi bakım ile ilgili çalışmalar 1960 'lı yıllara dayanmakta olup hemşirelerin manevi bakıma yönelik ilgisi giderek artmaktadır $^{8-11}$. Ülkemizde ise manevi bakım konusu 2000'li yıllardan sonra ilgi çekmeye başlayan güncel bir konu olmuştur ${ }^{12-15}$. Güncelliğini korumaktadı ${ }^{16-18}$. Ancak pediatri hemşirelerinin maneviyat ve manevi bakım hakkındaki görüşlerini inceleyen araştırmalar sınırlıdır ${ }^{19-21}$. Öte yandan hemşirelerin duygu gereksinimlerine yönelik çalışmalar da yok denecek kadar azdır22-24. Pediatri hemşirelerinin duygu gereksinimleri ile maneviyat ve manevi bakım hakkındaki görüşlerini ve bunlar arasındaki ilişkiyi inceleyen bir çalışmaya rastlanmamıştır. Pediatri kliniğinde çalışan hemşireler doğası gereği duygu yükü fazla olan bir ortamda çalışmaktadırlar. Pediatri hemşirelerinin, çocuk ve ailesinin fizyolojik, psikolojik, sosyokültürel ve manevi gereksinimlerini bir bütün olarak ele alabilmesi gerekir. Hemşirelerin duygusal durumları ve gereksinimleri manevi bakım ile ilgili görüşlerini ve uygulamalarını etkileyebilir bu nedenle araştırmada pediatri hemşirelerinin duygu gereksinimleri ile maneviyat ve manevi bakım hakkındaki görüşlerini ve etkileyen faktörleri belirlemek hedeflenmiştir.

\section{Araştırma Soruları}

1. Pediatri hemşirelerinin duygu gereksinimi düzeyleri nasıldır?
2. Pediatri hemşirelerinin maneviyat ve manevi bakıma ilişkin görüşleri nasıldır?

3. Pediatri hemşirelerinin sosyodemografik ve çalışma özellikleri, Duygu Gereksinimi Ölçeği (DGÖ) ve Maneviyat ve Manevi Bakım Dereceleme Ölçeği (MMBDÖ) puan ortalamalarını etkilemekte midir?

4. Pediatri hemşirelerinin DGÖ ile MMBDÖ puan ortalamaları arasında ilişki var mıdır?

\section{GEREÇ ve YÖNTEM}

\section{Araştırmanın Türü}

Araştırma, tanımlayıcı ve ilişki arayıcı türde bir çalışmadır.

\section{Araştırmanın Evreni ve Örneklemi}

Araştırmanın evreni çalışmaya izin veren hastanelerin pediatri kliniklerinde çalışan 328 hemşire olarak kabul edilmiştir. Araştırmada örneklem seçimine gidilmeden, evrenin tümüne ulaşılması hedeflenmiştir. Çalışmanın yapıldığı tarihlerde 11 hemşire yıllık izin veya doğum izninde, 9 hemşire üç aydan az çalışma süresine sahip olduğu, 8 hemşire araştırmaya katılmayı reddettiği için çalışma kapsamına alınmamıştır. Veriler toplandıktan sonra 20 soru formu eksik doldurulduğu için çalışmanın örneklemine dahil edilmemiş araştırmanın nihai örneklemi 280 pediatri hemşiresinden oluşmuştur. Araştırmaya katılım oranı \%85.4'tür.

\section{Araştırmaya Dahil Edilme Kriterleri}

Araştırmaya çalışmanın yapıldığı tarihlerde, çalışmaya izin veren hastanelerin pediatri kliniklerinde en az üç aydır aktif olarak çalışan ve araştırmaya katılmaya gönüllü olan hemşireler sözlü onamları alınarak dahil edilmiştir.

\section{Araştırmanın Yapıldığı Yer ve Özellikleri}

Araştırma Ağustos 2016-Mart 2017 tarihleri arasında, Konya il merkezinde yer alan araştırmanın yapılmasına izin veren iki devlet hastanesi, iki üniversite hastanesi ve bir özel hastanenin pediatri kliniklerinde çalışan hemşireler ile yürütülmüştür.

\section{Veri Toplama Araçları}

Araştırmanın verileri Kişisel Bilgi Formu, DGÖ ve MMBDÖ kullanılarak toplanmıştır.

Kişisel Bilgi Formu; Formda hemşirelerin sosyodemografik özellikleri (yaş, cinsiyet, öğrenim düzeyi, medeni durum, çocuk sahibi olma durumu) ile ilgili 5, çalışma özellikleri (çalışma yılı, çalışma şekli, birim vb.) ile ilgili 3, çocuk ve ailelerin manevi bakım gereksinimleri hakkındaki düşüncesi ve duygusal olaylara genel yaklaşımını içeren toplam 10 soru yer almıştır.

Duygu Gereksinimi Ölçeği (DGÖ); Maio ve Esses $(2001)^{25}$ tarafından geliştirilen DGÖ, Türkçe'ye Duyan ve ark. $(2011)^{26}$ tarafından uyarlanmıştır. Ölçek bireylerin duygu yüklü olaylara yaklaşma ve kaçınma motivasyonunu değerlendiren bir öz bildirim aracı olup 26 madde ve 2 alt boyuttan oluşmaktadır. Maddeler kesinlikle katılmıyorum ile kesinlikle katılıyorum arasında puanlanan 7'li likert tipinde bir ölçektir. Ölçeğin alt boyutları yaklaşma alt boyutu ve kaçınma alt boyutudur. Yaklaşma Alt Boyutu 2, 4, 5, 6, 7, 13, 15, 17, 18, 19, 20, 24 ve 26. maddeleri, Kaçınma Alt Boyutu 1, 3, 8, 9, 10, 11, 12, 14, 16, 21, 22, 23 ve 25. Maddelerini kapsamaktadır. Her bir alt boyuttan alınabilecek puanlar -39 ile +39 arasındadır. Ölçeğin toplam 
puanı hesaplanırken, kaçınma maddeleri ters puanlanmaktadır. Duyan ve ark. (2011) ${ }^{26}$ ölçeğin Cronbach alfa değerini 0.84 bulmuş olup bu çalışmada 0.81 olarak hesaplanmıştır. Ölçekten alınan yüksek puanlar insanların duygulara yaklaşma motivasyonunun yüksek, düşük puanlar ise duygulara yaklaşma motivasyonunun düşük olduğu anlamına gelmektedir.

Maneviyat ve Manevi Bakım Dereceleme Ölçeği (MMBDÖ); McSherry, Draper ve Kendric (2002) ${ }^{27}$ tarafından geliştirilmiş olan MMBDÖ 17 maddeden ve 3 alt boyuttan oluşan, $5^{\prime}$ li likert tipi bir ölçektir.

Maneviyat ve Manevi Bakım Alt Boyutu: 6, 7, 8, 9, 11, 12, 14. Sorular maneviyat ve manevi bakıma genel bakış açısını belirleyen toplam 7 maddeyi içerir.

Dinsellik Alt Boyutu: 4, 5, 13 ve 16. sorular dinsellik ile ilgili olup toplam 4 maddeyi içerir.

Bireysel Bakım Alt Boyutu: 1, 2, 10 ve 15 sorular bireysel bakım ile ilgili olup toplam 4 maddeyi içerir.

Maddelerin puanlaması, "kesinlikle katılmıyorum" ifadesini taşıyan 1'den "tamamen katılıyorum" ifadesini taşıyan 5'e doğru yapılmaktadır. Toplam madde puan ortalamasının 5'e yaklaşması maneviyat ve manevi bakım kavramlarının algılanma düzeyinin yüksek olduğunu göstermektedir. Ölçekten alınabilecek en düşük puan 17, en yüksek puan $85^{\prime}$ tir. Ölçekte $3,4,13$ ve 17 . maddeler olmak üzere toplam dört madde ters kodlanmaktadır. Ölçeğin orijinalinde alt boyutlar bulunmakla beraber Ergül ve Bayık-Temel'in (2007) ${ }^{13}$ Türkçe'ye uyarladığı geçerlik ve güvenirlik çalışmasında toplam puan üzerinden değerlendirilme yapılmasını önermektedirler. Madde toplam puan ortalamasının 5'e yaklaşması maneviyat ve manevi bakım kavramlarının algılanma düzeyinin yüksek olduğunu göstermektedir. Ergül ve Bayık-Temel'in (2007)13 çalışmasında Cronbach Alpha katsayısı 0.76 bulmuş olup bu çalışmada MMBDÖ için Cronbach Alpha katsayısı 0.89 bulunmuştur.

\section{Verilerin Toplanmas}

Verilerin toplanmasında kurum izinleri alındıktan sonra hemşireler işyerinde ziyaret edilerek araştırma hakkında bilgilendirilmiştir. Araştırmaya katılmaya gönüllü olanlara veri toplama formları verilerek hemşirelerinin birbirlerinden etkilenmelerini önlemek için gerekli tedbirler alınmıştır.

\section{Verilerin Değerlendirilmesi}

Çalışmanın verileri bilgisayar ortamında sayı, yüzde, ortalama ve standart sapma, bağımsız değikenlerin ölçek puanları üzerine etkisini incelemek amacıyla çoklu regresyon (Backward) ve ölçekler arası ilişkiyi saptamak için Pearson Korelasyon analizi kullanılmıştır. İstatistiksel değerlendirmede anlamlılık düzeyi $p<0.05$ olarak kabul edilmiştir.

\section{Araştırmanın Etik Boyutu}

Verileri toplamadan önce bir üniversitenin etik kurulundan (22.04.2016 tarihli 2016/521 karar sayısı) ve çalışmanın yürütüleceği tüm hastanelerden yazılı izin alınmıştır. Ayrıca, çalışmada yer alacak her birey çalışmanın içeriği hakkında bilgilendirilip ve sözlü onamları alınmıştır.

\section{BULGULAR}

Araştırmaya katılan pediatri hemşirelerinin \%80'inin kadın, $\% 42.1^{\prime}$ inin 25-29 yaş grubunda, \%58.2'sinin evli ve $\% 46.4$ 'ünün çocuk sahibi olduğu ve \%61.7'sinin lisans eğitim düzeyinde olduğu belirlenmiştir. Hemşirelerin \%45.6'sı genel çocuk servislerinde, \%32.9'u ise Yenidoğan yoğun bakım ünitesinde çalışmaktadır. Hemşirelerin \%40.4'ü 2-4 yıldır çalışmakta ve \%41.1'i günlük 1-7 arası hastaya bakım vermektedir. Hemşirelerin \%45'i duygusal olaylara yaklaştığını \%68.6'sı çocuk hastaların manevi bakıma gereksinimleri olduğunu düşündüğünü ifade etmiştir (Tablo 1).

Tablo 1. Pediatri Hemşirelerinin Sosyo-Demografik Özelliklerine Göre Dağılımı ( $n=280)$

\begin{tabular}{|c|c|c|}
\hline Özellik & $\mathbf{n}$ & $\%$ \\
\hline \multicolumn{3}{|l|}{ Cinsiyet } \\
\hline Kadın & 224 & 80.0 \\
\hline Erkek & 56 & 20.0 \\
\hline \multicolumn{3}{|l|}{ Yaş Grupları (X $\pm S S=29.12 \pm 6.08)$} \\
\hline $18-24$ & 58 & 20.8 \\
\hline $25-29$ & 118 & 42.1 \\
\hline $30-34$ & 44 & 15.7 \\
\hline 35 yaş ve üzeri & 60 & 21.4 \\
\hline \multicolumn{3}{|l|}{ Eğitim Durumu } \\
\hline Sağlık meslek lisesi & 52 & 18.6 \\
\hline Önlisans & 43 & 15.4 \\
\hline Lisans & 173 & 61.7 \\
\hline Yükseklisans/Doktora & 12 & 4.3 \\
\hline \multicolumn{3}{|l|}{ Çalıştığı Birim } \\
\hline Yenidoğan yoğun bakım & 92 & 32.9 \\
\hline Çocuk acil & 38 & 13.6 \\
\hline Çocuk yoğun bakım & 22 & 7.9 \\
\hline Diğer (süt çocuğu, çocuk cerrahisi...) & 128 & 5.9 \\
\hline \multicolumn{3}{|l|}{ Çalışma Şekli } \\
\hline Sürekli gündür & 70 & 25.4 \\
\hline Sürekli gece & 19 & 6.8 \\
\hline Gündüz ve gece & 190 & 67.8 \\
\hline \multicolumn{3}{|l|}{ Duygusal Olaylara Yaklaşım Şekli } \\
\hline Yaklaşırım & 126 & 45.0 \\
\hline Kararsızım & 96 & 34.3 \\
\hline Kaçınırım & 58 & 20.7 \\
\hline \multicolumn{3}{|l|}{ Çocukların Manevi Bakım } \\
\hline Gereksinimlerine Dair Düşünce & 192 & 68.6 \\
\hline Evet & 88 & 31.4 \\
\hline Hayır & & \\
\hline
\end{tabular}

Pediatri hemşirelerinin MMBDÖ madde puan ortalamaları $3.69 \pm .67$ (en yüksek 5 puan üzerinden) ve toplam puan ortalaması $62.67 \pm 11.31$ (17-85 puan üzerinden) olarak hesaplanmıştır. Hemşirelerin DGÖ toplamından aldıkları puanların ortalaması $16.16 \pm 19.15$ olarak bulunmuştur. Hemşirelerin DGÖ Yaklaşma alt boyutu puan ortalamalarının $7.31 \pm 12.62$ Kaçınma alt boyutu puan ortalamalarının $-8.85 \pm 11.50$ olduğu belirlenmiştir (Tablo 2 ). Tablo 2. Pediatri Hemşirelerinin MMBDö ile DGÖ Puanlarının Dağılımı ( $n=280)$

\begin{tabular}{|l|l|l|}
\hline Ölçek ve Alt Boyutları & Min-Max & $\mathbf{X} \pm \mathbf{S S}$ \\
\hline MMBDÖ Madde Puan Ortalaması & $1.6-4.8$ & $3.69 \pm .67$ \\
MMBDÖ Toplam Puan Ortalaması & $27-81$ & $62.67 \pm 11.31$ \\
\hline Yaklaşma Alt Boyutu & $-31-39$ & $7.31 \pm 12.62$ \\
Kaçınma Alt Boyutu & $-36-22$ & $-8.85 \pm 11.50$ \\
DGÖ Toplam Puan Ortalaması & $-42-59$ & $16.16 \pm 19.15$ \\
\hline
\end{tabular}


Hemşirelerin DGÖ Yaklaşma alt boyut puan ortalaması üzerine etkisi olduğu belirlenen (Anova ve $t$ testi sonucunda) altı bağımsız değişkenin etkisi çoklu regresyon analizi ile bir arada değerlendirilmiştir (Tablo 3). Bağımlı değişkenlerden Yaklaşma alt boyut puanını, yordayan değişken olarak

cinsiyet, eğitim düzeyi, medeni durum, serviste çalışma süresi, duygusal olaylara yaklaşım şekli ve manevi bakım gereksinimlerine ilişkin görüşleri çoklu regresyon modeline alınmıştır. Birinci modelde altı değişkenin yer aldığı analizde ikinci modelde medeni durum, üçüncü modelde cinsiyet değişkeni, dördüncü modelde çalışma süresi yeterli etkiye sahip olmadı̆̆ı için regresyon modelinden çıkarılmıştır. Modelde kalan değişkenlerin DGÖ Yaklaşma alt boyut puanına ait değişimi \%14 oranında açıkladığı görülmüştür. Hemşirelerin yaklaşma alt boyut puanında; duygusal olaylara yaklaşma şekli (Yaklaşırım:1 Kaçınırım:2) kaçınmaktan yaklaşmaya doğru gittikçe 3.92 puanlık artışa, eğitim düzeyi (Lise:1 Önlisans:2 Lisans ve üzeri:3) ön lisanstan lisans ve üstüne doğru yükseldikçe 2.12 puanlık artışa, çocukların manevi bakım gereksinimleri olup olmadığı konusunda hayır diyenlerde evet diyenlere göre 4.58 puanlık azalmaya yol açtığı görülmüştür.

Tablo 3. Pediatri Hemşirelerinin DGÖ Alt Boyutları Toplam Puanlarına Etkisi Olan Bağımsız Değişkenlerin Değerlendirilmesi $(n=280)$

\begin{tabular}{|c|c|c|c|c|c|c|c|}
\hline $\begin{array}{l}\text { DGÖ Yaklaşma Alt } \\
\text { Boyutu Puanına } \\
\text { Etkisi Olan Bağımsız } \\
\text { Değişkenler }\end{array}$ & B & $\begin{array}{c}S . \\
\text { Hata }\end{array}$ & Beta ( $\beta$ ) & $\mathrm{t}$ & $p$ & \multicolumn{2}{|c|}{$\begin{array}{l}\text { 95\% Güven } \\
\text { Aralığı }\end{array}$} \\
\hline (Sabit) & -4.74 & 4.42 & & -1.07 & .284 & -13.43 & 3.95 \\
\hline $\begin{array}{l}\text { Duygusal olaylara } \\
\text { yaklaşım şekli }\end{array}$ & 3.2 & .94 & .24 & 4.19 & .000 & 2.08 & 5.76 \\
\hline $\begin{array}{l}\text { Çocukların manevi } \\
\text { bakım } \\
\text { gereksinimlerine } \\
\text { dair düşünce }\end{array}$ & -4.58 & 1.56 & -.17 & -2.92 & .004 & -7.66 & -1.50 \\
\hline Eğitim & 2.12 & .75 & .16 & 2.84 & .005 & .66 & 3.59 \\
\hline \multicolumn{8}{|c|}{$\begin{array}{l}\text { Bağımlı değişken: Yaklaşma alt boyutu puanı R:.39, Adjusted R²:.14, F:12.523, p:.000, Durbin } \\
\text { Watson:1.99 }\end{array}$} \\
\hline $\begin{array}{l}\text { DGÖ Kaçınma Alt } \\
\text { Boyutu Puanına } \\
\text { Etkisi Olan Bağımsız } \\
\text { Değişkenler }\end{array}$ & B & $\begin{array}{c}S . \\
\text { Hata }\end{array}$ & Beta ( $\beta$ ) & $\mathrm{t}$ & $\mathbf{p}$ & \multicolumn{2}{|c|}{$\begin{array}{l}\text { 95\% Güven } \\
\text { Aralığı }\end{array}$} \\
\hline (Sabit) & -2.21 & 5.04 & & -.438 & .662 & -12.12 & 7.71 \\
\hline $\begin{array}{l}\text { Duygusal olaylara } \\
\text { yaklaşım şekli }\end{array}$ & -1.87 & .86 & -.13 & -2.18 & .030 & -3.56 & -.18 \\
\hline $\begin{array}{l}\text { Çocukların manevi } \\
\text { bakım } \\
\text { gereksinimlerine } \\
\text { dair düşünce }\end{array}$ & 3.48 & 1.48 & .14 & 2.35 & .019 & .58 & 6.38 \\
\hline Çalışma süresi & -3.11 & 1.37 & -.13 & -2.27 & .024 & -5.81 & -.41 \\
\hline Cinsiyet & 4.45 & 1.67 & .16 & 2.65 & .008 & 1.15 & 7.75 \\
\hline Eğitim durumu & -4.03 & 1.69 & -.14 & -2.38 & .18 & -7.35 & -.71 \\
\hline
\end{tabular}

Hemşirelerin DGÖ Kaçınma alt boyut puan ortalaması üzerine etkisi olduğu belirlenen beş bağımsız değişkenin etkisi çoklu regresyon analizi ile bir arada değerlendirilmiştir. Bağımlı değişken olarak Kaçınma alt boyut puanı, yordayan değişken olarak cinsiyet, eğitim düzeyi, serviste çalışma süresi, duygusal olaylara yaklaşım şekli ve çocukların manevi bakım gereksinimleri olup olmadığı görüşü çoklu regresyon modeline alınmıştır. Beş değişken hemşirelerde DGÖ Kaçınma alt boyut puanına ait değişimi \%14 oranında açıklamaktadır. Hemşirelerin Kaçınma alt boyut puanında; erkekler 4.45 puanlık, çocukların manevi bakıma gereksinimleri olmadığını düşünen (Var:1 Yok:2) hemşireler 3.48 puanlık artışa neden olmaktadır. Kaçınma alt boyut puanlarında eğitim düzeyi (Lise:1 Önlisans:2 Lisans ve üzeri:3) ön lisanstan lisans ve üstüne doğru yükseldikçe -4.03 puanlık, serviste çalışma süresi 2 yıl ve fazla olanlar -3.11 puanlık, duygusal olaylara yaklaşan hemşireler -1.87 puanlık azalmaya neden olmaktadır (Tablo 3).

Hemşirelerin MMBDÖ toplam puanı üzerine etkisi olduğu belirlenen (Anova ve $t$ testi sonucunda) üç değişkenin etkisini bir arada değerlendirmek için çoklu regresyon analizi yapılmıştır. Birinci modelde üç değişkenin yer aldığı analizde "çocuk sahibi olma" yeterli etkiye sahip olmadığı için regresyon modelinden çıkarılmıştır. Hemşirelerde iki değişkenin maneviyat ve manevi bakım puanına ait değişimi \%6 oranında açıkladığı belirlenmiştir. İki değişkendeki puan artışı maneviyat ve manevi bakım puanını azaltma yönünde etkilemektedir. Çocukların manevi bakıma gereksinimleri olup olmadığı (gruplar; evet:1; hayır:2) konusunda hayır diyenlerin puanında evet diyenlerinkine göre -.31 puanlık azalmaya, medeni durumu (Evli: 1 bekar: 2) bekar olanların puanında ise evli olanlarınkine göre -.16 puanlık azalmaya yol açtığı görülmüştür (Tablo 4).

Tablo 4. Pediatri Hemşirelerinin MMBDö Toplam Puanlarına Etkisi Olan Bağımsız Değişkenlerin Değerlendirilmesi ( $\mathbf{n = 2 8 0 )}$

\begin{tabular}{|c|c|c|c|c|c|c|c|}
\hline $\begin{array}{l}\text { MMBDÖ } \\
\text { Toplam } \\
\text { Puanına Etkisi } \\
\text { Olan } \\
\text { Değişkenler }\end{array}$ & B & $\begin{array}{l}\text { S. } \\
\text { Hata }\end{array}$ & $\begin{array}{l}\text { Beta } \\
\text { ( } \beta)\end{array}$ & $t$ & $p$ & \multicolumn{2}{|c|}{$\begin{array}{l}\text { 95\% Güven } \\
\text { Aralığı }\end{array}$} \\
\hline (Sabit) & 4.32 & .15 & & 29.12 & .00 & 4.03 & 4.61 \\
\hline $\begin{array}{l}\text { Çocukların } \\
\text { manevi bakım } \\
\text { gereksinimleri } \\
\text { ne dair } \\
\text { düşünce } \\
\end{array}$ & -.31 & .08 & -.22 & -3.70 & .00 & -.48 & -.15 \\
\hline $\begin{array}{l}\text { Medeni } \\
\text { Durum }\end{array}$ & -.16 & .08 & -.12 & -1.99 & .047 & -.31 & -.00 \\
\hline
\end{tabular}

Hemşirelerin MMBDÖ puanları ile DGÖ toplam puanları ve DGÖ Yaklaşma alt boyut puanları arasında pozitif yönde anlamlı bir ilişki olduğu belirlenmiştir (Tablo 5). Hemşirelerin MMBDÖ puanları arttıkça DGÖ toplam puanları da artmıştır. Benzer şekilde hemşirelerin MMBDÖ puanları arttıkça DGÖ Yaklaşma alt boyutu puanları da anlamlı şekilde artış göstermiştir. Hemşirelerin MMBDÖ puanları ile DGÖ Kaçınma alt boyut puanları arasında ise negatif yönde istatistiksel olarak anlamlı bir ilişki olduğu belirlenmiştir. Hemşirelerin MMBDÖ puanları arttıkça DGÖ Kaçınma alt boyut puanları da azalmaktadır (Tablo 5). 
Tablo 5. P Pediatri Hemşirelerinin MMBDö Puanları ile DGÖ ve Alt Boyutları Puanlarının Iliş̧kisi $(\mathbf{n}=\mathbf{2 8 0})$

\begin{tabular}{|l|c|l|}
\hline DGÖ ve Alt boyutları & \multicolumn{2}{l|}{ MMBDÖ Toplam } \\
& Puanı \\
\hline & $\mathbf{r}$ & $\mathbf{p}$ \\
\hline DGÖ Toplam Puanı & .35 & $<0.001$ \\
\hline DGÖ Yaklaşma alt boyutu & 30 & $<0.001$ \\
\hline DGÖ Kaçınma alt boyutu & -.25 & $<0.001$ \\
\hline
\end{tabular}

\section{TARTIŞMA}

Manevi bakım hemşirelik etik kodları ve kuramlarının üzerinde önemle durduğu insanların hayata bağlılıklarını arttıran ve korkularını gidermeyi amaçlayan duygu yüklü bir bakımdır. Manevi bakım uygulamaları hemşirelerin bakım verici rolleri arasında yer almaktadır ${ }^{28,29}$. Hemşirelerin duygusal olaylara yaklaşma-kaçınma motivasyonlarının incelenmesi duygu yüklü uygulamalara olan bakış açılarını anlamak için önemlidir. Çalışmamıza katılan pediatri hemşirelerinin MMBDÖ puanları Kostak ve arkadaşlarının (2010)15 hemşire ve ebelerle yaptıkları çalışmalarında bulduğu puanlarla $(60.97 \pm 7.92)$ benzer iken Yılmaz ve Okyay'ın (2009) ${ }^{14} 54.57 \pm 5.09$, Özbaşaran ve arkadaşlarının $(2011)^{28} 3.21 \pm .63$, Çelik-Sis ve arkadaşlarının $(2014)^{29}$ $53.40 \pm 5.33$, Eğlence ve Şimşek'in $(2014)^{30} 3.11 \pm 0.41$ ve Gönenç ve arkadaşlarının $(2016)^{17} 47.71 \pm 4.93$ bulduğu değerlerden daha yüksek olduğu görülmektedir. Pediatri kliniklerinde çalışan hemşirelerin MMBDÖ puanlarının genel olarak daha yüksek olduğu görülmektedir. İnsanlar fizyolojik, psikolojik ve bilişsel tüm süreçlerde duygularını yeryüzündeki diğer tüm türlerden daha fazla kullanırlar ve bir çeşit duygusal deneyim zenginliği yaşarlar. Bu yüzden insan duygularının davranış psikolojisi üzerine önemli etkileri olduğu düşünülmektedir. Pediatri kliniklerinde çalışan hemşireler diğer kliniklerde çalışan hemşire ve ebelere kıyasla daha fazla duygusal olaylara şahit olmakta, hasta çocuk ve ailesiyle birebir ilgilenip bakımından sorumlu olmaktadır. Bu sebeple pediatri hemşirelerinin "iyi” düzeyde olan MMBDÖ puanlarının daha iyi düzeye çıkarılmasının bakımın kalitesinin yükseltilmesi açısından yararlı olacağı düşünülmektedir.

Araştırmada pediatri hemşirelerinin medeni durumu ve çocuk sahibi olma özelliklerinin MMBDÖ puanları ile anlamlı ilişkisinin olduğu ve puan değişiminin \%6.4'ünü açıkladığı görülmektedir. Bekar olmanın manevi bakım puanında -.16 puanlık azalmaya yol açtığı saptanmıştır. Benzer şekilde Cavendish ve arkadaşları (2004) ${ }^{31}$ çalışmalarında medeni durumu evli olan bireylerin MMBDÖ puanını anlamlı şekilde yüksek olduğunu bildirmiştir $(p<0.05)$. Özbaşaran ve arkadaşları (2011) ${ }^{28}$ bekar olan bireylerin MMBDÖ puanlarının anlamlı şekilde yüksek olduğunu belirlemişlerdir. Literatürde medeni durum ve çocuk sahibi olmanın MMBDÖ puanını arttırdığını ya da etkilemediğini bildiren araştırmalar da bulunmaktadır14,32-34. Çocuk hastaların manevi bakıma gereksinimi olduğunu düşünen hemşirelerin MMBDÖ puanı anlamlı şekilde yüksek bulunmuştur $(p<0.05)$. Çocuk hastaların manevi bakıma gereksinimi olmadığını düşünmenin manevi bakım puanında -.31 puanlık azalmaya yol açtığı tespit edilmiştir. Yılmaz ve Okyay $(2009)^{14}$, Kavak ve arkadaşları (2014) ${ }^{33}$ çalışmalarında manevi bakım verdiğini belirten hemşirelerin MMBDÖ puanlarının yüksek olduğunu bildirmişlerdir. Bu bulgular hemşirelerin manevi bakım konusundaki görüşlerinin manevi bakım puanları ile ilişkili olduğunu göstermektedir. Pediatri hemşirelerinin manevi bakım hakkındaki düşüncelerinin olumlu olması manevi bakım uygulamalarının yükseltilebilmesi bakımdan önem taşımaktadır.

Araştırmada pediatri hemşirelerinin DGÖ toplam puan ortalaması $16.16 \pm 19.15$, yaklaşma alt boyut puan ortalaması $7.31 \pm 12.62$ ve kaçınma alt boyut puan ortalaması $8.85 \pm 11.50$ olarak belirlenmiştir. Dil ve Aykanat $(2013)^{22}$ Hemşirelik öğrencilerinin Ruh Sağlığı ve Hastalıkları Hemşireliği Dersi öncesinde DGÖ yaklaşma alt boyut puan ortalamasını $15.62 \pm 9.89$ ders sonrasında $27.17 \pm 10.91$, kaçınma alt boyut puanını $-9.77 \pm 11.32$ ders sonrasında $8.40 \pm 12.65$ olarak bulmuşlardır. Aşık ve Albayrak (2016) ${ }^{24}$ Hemşirelik öğrencilerinde yaptıkları çalışmada DGÖ yaklaşma alt boyut puanını Hemşirelik öğrencilerinin Ruh Sağlığı ve Hastalıkları Hemşireliği Dersi öncesinde 16.52 \pm 8.9 , ders sonrasında $12.45 \pm 11.98$, kaçınma alt boyut puanını ise ders öncesinde $7.00 \pm 12.33$, ders sonrasında $-9.00 \pm 10.048$ olarak bulmuşlardır. $\mathrm{Bu}$ araştırma bulguları dikkate alındığında pediatri hemşirelerinin duygulara yaklaşma alt boyutu puanlarının hemşirelik öğrencilerinin puanlarından oldukça düşük olduğu dikkat çekmektedir. Öte yandan öğrencilerin duygulara yaklaşma puanlarının Dil ve Aykanat $(2013)^{22}$ çalışmasında ders sonrasında anlamlı şekilde yükselirken Aşık ve Albayrak (2016)'ın ${ }^{24}$ çalışmasında anlamlı şekilde düştüğü görülmektedir. Bu sonuçlar hemşirelerin duygu gereksinimlerine yönelik çalışmaların az olduğunu ve sonuçlarda uzlaşma olmadığını ortaya koymaktadır. Oysa hemşirelerin özellikle de pediatri hemşirelerinin duygulara yaklaşma düzeylerinin gelişmesi çocuk ve ailesini holistik açıdan ele alabilmesi, bakım kalitesi ve hemşirelerin kendi duygularıyla baş etme yöntemlerini geliştirebilmeleri açısından önemlidir.

Çalışmada cinsiyet ile DGÖ, duygulara yaklaşma ve kaçınma alt boyutları toplam puanları arasında anlamlı bir ilişki olduğu tespit edilmiştir $(p<0.05)$. Kadın hemşirelerin DGÖ ve yaklaşma alt boyut puanının erkek hemşirelere göre anlamlı şekilde yüksek olduğu saptanmıştır. Kaçınma alt boyut puanlarında ise erkeklerin puanlarının anlamlı şekilde daha yüksek olduğu bulunmuştur. Çalışmaya benzer şekilde DGÖ ve alt boyutlarının cinsiyete göre farklılık gösterdiğini belirten, kadınların DGÖ ve yaklaşma alt boyut puanlarının ve erkeklerin kaçınma alt boyut puanlarının anlamlı şekilde yüksek olduğunu ortaya koyan araştırmalar mevcuttur ${ }^{23,25}$. Farklı olarak DGÖ ve alt boyutlarının cinsiyetten etkilenmediğini ifade eden çalışmalara da rastlanmaktadır22,35. Literatür, cinsiyet faktörünün günlük davranışlar ve duygusal tercihler üzerinde açık etkisi olduğunu bildirmektedir. Duygular ve duygu gereksinimi üzerine yapılan birçok çalışmada kadınların duygusal deneyimleri yaşamaya daha açık olduğunu, erkeklerin ise duygularını istemli olarak bastırabildikleri bildirilmiştir ${ }^{25,35-}$ 38. Hemşirelik mesleği varoluşundan bu yana şefkat ve duygu temellidir. Kadınların doğası gereği şefkatli ve duygusal olmaları, duygu gereksinimlerinin ve duygulara yaklaşma 
eğilimlerinin fazla olması ile açıklanabilir ${ }^{39,40}$. Çalışmada pediatri hemşirelerinin DGÖ ve yaklaşma alt boyut puanları ile medeni durumları arasında anlamlı bir ilişki olduğu saptanmıştır ( $p<0.05)$.

Çocuk sahibi olan hemşirelerin ise DGÖ toplam puanının anlamlı şekilde yüksek olduğu belirlenmiştir. Bu sonuçlar doğrultusunda evli ve çocuk sahibi olan bireylerde değişen yaşamlarıyla birlikte sosyal, kültürel, çevresel ve manevi sorumluluklarının etkili olduğu düşünülebilir. Pediatri hemşirelerinin eğitim durumları ile DGÖ, yaklaşma ve kaçınma alt boyutları arasında anlamlı bir ilişki olduğu, Sağlık Meslek Lisesi (SML) mezunu hemşirelerin DGÖ, yaklaşma alt boyut puanlarının diğer gruplardan düşük olduğu tespit edilmiştir $(p<0.05)$. Yapılan regresyon analizine göre de eğitimin DGÖ, yaklaşma ve kaçınma alt boyut puanlarını etkilediği, eğitim durumu SML'den lisans ve üstüne doğru gittikçe DGÖ ve yaklaşma motivasyonunun arttığı, kaçınma motivasyonunun ise azaldığı görülmüştür. Duygusal olaylara yaklaşma, ağrı çeken bireyi anlama, empati kurma, hoşgörü ve sevgi gösterme vb. gibi duygusal durumlara müdahale etme becerileri eğitim ile kazanılan becerilerdir. Lisans ve lisansüstü eğitim alan hemşirelerin duygusal olaylara yaklaşma becerilerinin daha yüksek olması eğitim kazanımları ile açıklanabilir. Çalışma süresinin DGÖ ve kaçınma puanını etkilediği, deneyimi 2 yıldan az olanların duygulardan daha fazla kaçındığı belirlenmiştir $(p<0.05)$. Bu sonuçlara göre mesleki deneyimi 5 yılın altında olan hemşirelerin mesleki deneyimlerinin azlığı onların duygusal olaylara yaklaşma becerilerini etkilediği ve duygulardan kaçınmalarına yol açtığı görülmektedir. Mesleğe yeni başlayan hemşirelerin duygu gereksinimleri yönünden desteklenmesi yararlı olacaktır. Araştırmada duygusal olaylara yaklaştığını ifade eden hemşirelerin duygulara yaklaşma motivasyonunu daha fazla sergilediği ortaya çıkmıştır $(p<0.05)$. Hemşirelerin kendi duygularını ve duygulara yaklaşma durumlarını değerlendirmelerinin örtüştüğü görülmektedir. Çocuk hastaların manevi bakıma gereksinimleri olduğunu ifade eden hemşirelerin DGÖ ve yaklaşma alt boyut puanı anlamlı şekilde yüksek bulunmuştur $(p<0.05)$. Ayrıca çocukların manevi bakım gereksinimi olmadığını düşünen hemşirelerin duygulardan daha fazla kaçındığı saptanmıştır. Maneviyat beden, zihin, ruh ve duygularla ayrılmayacak kadar bir bütündür ${ }^{38}$. Bu sonuç duygusal olaylardan kaçınan hemşirelerin hastaların manevi bakım gereksinimlerinin farkında olamayacağını düşündürmektedir.

Araştırmada kullanılan iki ölçeğin ilişkisi incelendiğinde duygulara yaklaşma motivasyonu arttıkça hemşirelerin manevi bakım puanlarının arttığı, duygulardan kaçınma motivasyonu arttıkça manevi bakım puanlarının azaldığı gözlenmiştir. Bu sonuçlar hemşirelerin duygusal olaylara yaklaşma veya kaçınma durumlarının onların sunacağı manevi bakım uygulamalarını etkileyebileceğini göstermektedir. Hemşirelerin duygusal olaylarla başa çıkma becerilerinin geliştirilmesinin onların hastalarına sunacağı manevi bakım uygulamalarını geliştireceği düşünülebilir.

\section{SONUÇ ve ÖNERILER}

Pediatri kliniklerinde çalışan hemşirelerin duygu gereksinimleri ile maneviyat ve manevi bakım hakkındaki görüşlerinin incelenmesi amacıyla yürütülen bu çalışmada; hemşirelerin MMBDÖ puanlarının "iyi" düzeyde olduğu, hemşirelerin manevi bakım konusundaki düşüncelerinin de MMBDÖ puanlarını etkilendiği tespit edilmiştir. Bu sonuç öncelikle bekar ve manevi bakımın gerekli olmadığını düşünen hemşireler başta olmak üzere tüm pediatri hemşirelerinin manevi bakım konusunda geliştirilmesi için hizmet içi eğitimlerin gerektiğini ortaya koymaktadır. Araştırmada pediatri hemşirelerinin duygulara yaklaşma motivasyonu puanlarının orta düzeyin altında, duygulardan kaçınma durumlarının ise fazla olduğu sonucu ortaya çıkmıştır. Çocukların manevi bakıma gereksinimi olmadığını düşünen, öğrenim durumu lisans düzeyinden aşağı olan ve duygusal olaylardan kaçındığını ifade eden hemşirelerin DGÖ yaklaşma motivasyonlarının düşük olduğu belirlenmiştir. Diğer taraftan erkek hemşirelerin ve çocukların manevi bakım gereksinimi olmadığını düşünen tüm hemşirelerin, öğrenim düzeyi SML ve önlisans olan, çalışma deneyimi iki yılın altında olan hemşirelerin DGÖ kaçınma puanlarının yüksek olduğu yani duygusal olaylara yaklaşmaktan kaçındıkları sonucuna ulaşılmıştır. Hemşirelerin duygusal olaylara yaklaşma becerilerinin geliştirilmesine yönelik programlar geliştirilmesi, stres ve duygu gereksinimine yönelik destek gruplarının oluşturularak kurum içi eğitim programlarına dahil edilmesi önerilmektedir.

Etik Kurul Onayı: Bu çalışma için Necmettin Erbakan Üniversitesi, 22.04.2016 tarihli 2016/521 karar sayılı etik kurul onayı alınmıştır.

Çıkar Çatışması: Bildirilmemiştir.

Finansal Destek: Yoktur.

Katılımcı Onamı: Hemşirelerden bilgilendirilmiş onam alınmıştır.

Yazar katkıları:

Fikir: HKS, EG

Tasarım: HKS, EG

Denetleme/Danışmanlık: EG

Veri Toplama ve İşleme: HKS

Analiz ve Yorum: HKS, EG

Kaynak Taraması: HKS

Makalenin Yazımı: HKS, EG

Eleştirel İnceleme: HKS, EG

Kaynaklar ve Fon Sağlama: HKS, EG

Malzemeler: HKS

Teşekkür

Çalışmaya katılan tüm hemşirelere teşekkür ederiz.

Ethics Committee Approval: Necmettin Erbakan University approval for this study was obtained from the ethical committee numbered 2016/521 dated 22.04.2016.

Confict of Interest: Not reported.

Funding: None.

Exhibitor Consent: Informed consent was obtained from nurses. 


\section{Author contributions:}

Idea: HKS, EG

Design: HKS, EG

Supervision / Consulting: EG

Data Collection and Processing: HKS

Analysis and Interpretation: HKS, EG

Literature Survey: HKS

Writing of the Article: HKS, EG

Critical Review: HKS, EG

Sources and Funding: HKS, EG

Materials: HKS

Acknowledgement: We would like to thank all nurses who participated to the study.

\section{KAYNAKLAR}

1. Dossey BM, Lynn K. Holistic nursing a handbook for practice. USA: Jones and Bartlett Learning;2009.

2. Conk Z, Başbakkal Z, Bal Yılmaz H, Bolışık B. Pediatri Hemşireliği. Ankara: Akademisyen Kitabevi;2018.

3. Kanwal N, Afzal M, Kousar R, Waqas A, Gilani SA. Assess spirituality and spiritual care in nursing practice in Public Hospital Lahore, Pakistan. Saudi Journal of Medical and Pharmaceutical Sciences. 2017;3(6B):596607.

4. Wright S. The heart and soul of nursing. Nursing Standart. 2011;25(30):18-20.

5. Meehan TC. Spirituality and spiritual care from a careful nursing perspective. J Nurs Manag. 2012;20:990-1001.

6. Hockenberry MJ, Wilson D. Essential of pediatric nursing. USA:Elsevier; 2013.

7. Sülü-Uğurlu E, Başbakkal Z (2013). Yoğun bakımda yatan çocukların annelerinin manevi bakım (spiritüal bakım) gereksinimleri. J Turk Soc Intens Care. 2013;11(1):17.

8. Hubert M. Spiritual care for every patient. Journal of Nursing Education. 1963;2(2):9.

9. Sullivan M. A Survey Of The Spiritual Care Administered To The Hospitalized Patient By The Student Nurse In The Four Catholic Hospitals In The State Of Montana [Nursing Undergraduate Theses]. Montana: Carroll College;1964.

10. Alfaro de Sánchez $A M$, GomesPinal $L$, de Castro AD, PinedaMoreno A, López Sandoval J. Nouv. Christian spirituality challenge to the nurse. Nouv Com Int Cathol Infirm Assist Med Soc. 1980;(2):38-42.

11. Ergül Ş, Bayık A. Hemşirelik ve manevi bakım. Cumhuriyet Üniversitesi Hemşirelik Yüksek Okulu Dergisi. 2004;8(1):37-45.

12. Çetinkaya B, Altundağ S, Azak A. Spirituel bakım ve hemşirelik. ADÜ Tıp Fakültesi Dergisi. 2007;8(1):47-50.

13. Ergül Ş,Bayık-Temel A. Maneviyat ve manevi bakım dereceleme ölçeğinin Türkçe formunun geçerlilik ve güvenilirliği. Journal of Ege University Nursing Faculty. 2007;23 (1):75-87.

14. Okyay N, Yılmaz M. Hemşirelerin maneviyat ve manevi bakıma ilişkin görüşleri. HEMAR-G. 2009;3:42-45.
15. Kostak MA, Çelikkalp MÜ, Demir M. Hemşire ve ebelerin maneviyat ve manevi bakıma ilişkin düşünceleri. Maltepe Üniversitesi Hemşirelik Bilim ve Sanatı Dergisi Sempozyum Özel Sayısı. 2010:220-225.

16. Yılmaz M. Holistik bakımı bir boyutu: spiritualite doğası ve hemşirelikle ilişkisi. Journal of Anatolia Nursing and Health Sciences. 2011;14(2):61-69.

17. Gönenç IM, Akkuzu G, Altın DR, Möroy P. Hemşirelerin ve ebelerin manevi bakıma ilişkin görüşleri. Gumushane University Journal of Health Science. 2016;5(3):34-38.

18. Midilli TS, Kalkım A, Dağhan Ş. Hemşirelik öğrencilerinin manevi bakıma ilişkin görüş ve uygulamaları. Journal of Human Science. 2007;14(1):665-677.

19. Bull A, Gillies M. Spiritual needs of children with complex health care needs in the hospital. Paediatric Nursing. 2007;19(9):34-38.

20. Nascimento $\mathrm{CL}$, Santos de Oliveira FC, Moreno MF, Machado da Silva F. Spiritual care: an essential component of the nurse practice in pediatric oncology. Acta paul. Enferm. 2010;23(3).

21. Oberholzer A. The spiritual needs of a child in hospital: nurturing the vessel within. Pharos Journal of Theology. 2016;97,ISSN 2414-3324.

22. Dil S, Aykanat B. Ruh sağlığı ve hastalıkları hemşireliği dersi alan ve almayan öğrencilerin duygusal durumlara yaklaşma-kaçınma motivasyon düzeylerine etkisi. Journal of Psychiatric Nursing. 2013;4(3):125-130.

23. Metin Ö. Hemşirelik öğrencilerinin empatik eğilim düzeyleri ile duygusal durumlara yaklaşma ve kaçınma motivasyonları [Yüksek lisans tezi]. İstanbul: Haliç Üniversitesi; 2015.

24. Aşık E, Albayrak $\mathrm{S}$. Ruh sağlığı ve hastalıkları hemşireliği dersi alan ve almayan öğrencilerin duygusal durumlara yaklaşma-kaçınma düzeyleri ve problem çözme algıları. KOU Sag Bil Derg. 2016;1:39-43.

25. Maio GR, Esses VM. The need for affect: individual differences in the motivation to approach or avoid emotions. Journal of Personality. 2001; 69(4):583-615.

26. Duyan V, Uçar ME, Kalafat T. Duygu gereksinimi ölçeğinin Türk kültürüne uyarlanması ve psikometrik niteliklerinin belirlenmesi. Education and Science. 2011;36(161):116-129.

27. McSherry W, Draper P, Kendrick D. The Construct validity of a rating scale designed to assess spirituality and spiritual care, IJNS. 2002;39:723-734.

28. Özbaşaran F, Ergül Ş, Bayık-Temel A, Aslan G, Çoban A. Turkish nurse's perceptions of spirituality and spiritual care. JCN. 2011;20(21-22):3102-3110.

29. Çelik-Sis A, Özdemir F, Durmaz H, Pasinlioğlu T. Hemşirelerin maneviyat ve manevi bakımı algılama düzeyleri ve etkileyen bazı faktörlerin belirlenmesi. Journal of Hacettepe University Faculty of Nursing. 2014;1:1-12.

30. Eğlence R. Şimşek N. Hemşirelerin maneviyat ve manevi bakım hakkındaki bilgilerinin değerlendirilmesi. Acibadem University Health Sciences Journal. 2014; 1:48-53. 
31. Cavendish R, Luise BK, Russo D, Mitzeliotis C, Bauer M, Bajo MAM et al. Spiritual perspectives of nurses in the United. States relevant for education and practice. WJNR. 2004;26:196-212.

32. Yılmaz G. Durmaz BG. Pediatri hemşirelerinin empatik eğilim, duygusal emek davranışları ve tükenmişlik düzeyleri arasındaki ilişki. Journal of Hacettepe University Faculty of Nursing. 2019;6(2):92-100.

33. Kavak F, Mankan T, Polat H, Sarıtaş-Çıtak S, Sarıtaş $S$. Hemşirelerin manevi bakıma ilişkin görüşleri. İnönü Üniversitesi Sağlık Bilimleri Dergisi. 2014; 3(1):21-24.

34. İnce-Çelik S, Akhan-Utaş L. Öğrenci Hemşirelerin maneviyat ve manevi bakıma ilişkin algıları. HEAD. 2016;13(3):202-208.

35. Altuntaş $\mathrm{O}$, Altuntaş $\mathrm{HH}$. Yaratıcı drama yönteminin üniversite öğrencilerinin duygusal gereksinimleri üzerine etkisi. Electronic Turkish Studies. 2015;10(11):113-126.

36. Lewis M, Haviland-Jones MJ, Barrett L. Handbook of emotions. Newyork USA:The Guilford Press;2010.

37. Soslau E. Student-teachers' emotional needs and dichotomous problem-solving: non-cognitive root causes of teaching and learning problems. Educational Action Research. 2016;24(4):49-502.

38. Baldacchino DR. Spiritual care education of health care proffesionals. Religions. 2015;6:594-613.

39. Dolan RJ. Emotion, cognition and behavior. Science. 2002;298:1191-1195.

40. Thill S, Lowe R. On the functional contributionsof emotion mechanisms to (artificial) cognition and intelligence. In: Bach J, Goertzel B, Ikle M. (eds) Artificial General Intelligence. AGI. 2012;7716. 